\title{
CLUSTER INITIATIVE IN THE SLOVAK REPUBLIC
}

\author{
Denisa Janasová, ${ }^{1}$ Stanislava Strelcová ${ }^{2}$
}

\begin{abstract}
This article examines the environmental conditions forming the origin and development of clusters in the Slovak Republic. It focuses on the current information and financial support for clusters, the preferred legal form of these associations in the Slovak Republic, and the possible forms of cross-border cooperation. The aim of this article is to analyze the structure of clusters in the Slovak Republic. The paper features an overview of the possible number and focus of clusters, including the procedure for identifying clusters needed to create this list. Despite its stated limitations, this indicative list provides a basis for further research in this area.
\end{abstract}

JEL Classification Numbers: M21, R12; DOI: http://dx.doi.org/10.12955/cbup.v5.925

UDC Classification: 338.1

Keywords: cluster, small and medium-sized enterprises, risks

\section{Introduction}

According to Porter (1998), a cluster is a geographically close group of mutually interconnected companies, suppliers, and institutions in a particular branch. It is usual for companies as well as educational institutions, research centers, regional self-government, and agencies supporting the business development and the region itself to form clusters (Duman, Balog, Rehák, Zaušková \& Loučanová, 2009). The value of clusters for companies entails increased productivity and competitiveness, both on the national and international level. For educational institutions, clusters allow the opportunity for dual education for practical needs as well as the applied research and transfer of technologies into practice. Their formation primarily benefits the economy but also helps in supporting infrastructure development for the regions or the regional self-governments.

\section{Support of Clusters in the Slovak Republic}

The emergence of the first Slovak Republic clusters was mainly an initiative of Slovak companies in a certain line of business or region. The legal form of such companies' association depended especially on valid legislation of the particular country. The clusters in the Slovak Republic are mainly established as 'interest associations of the legal entities' and 'citizens' associations.' These two preferred legal forms appear to be the most suitable since as no legal basis exists for their founding. The official means of the government support for the clusters were provided for the first time in 2012 by the Ministry of Education, Research, and Sport of the Slovak Republic through subsidies aimed at scientific and technical services (Kaliňák, 2012). Further, the Ministry of Economy intend covering the support of clusters through the Scheme for Support of Industrial Cluster Organisations, from 2018. In 2016, seven applicants obtained subsidies to support industrial clusters while three were rejected (Zoznam, 2016). Only clusters with the legal form of 'interest associations of the legal entities' can obtain such subsidies (Schéma, 2014). However, a cluster with the legal form 'citizens' association' can apply for a subsidy through the Ministry of Economy, based on legislation about providing subsidies (Law No. 71/2013 Coll.) issued by the Ministry of Economy. Based on this law, the purpose of a subsidy for clusters can be to support small and medium enterprises, research, development, and innovations, or development of the industrial production and services (Law No. 71/2013, Coll.). Regardless of the legal form of the tourism clusters, the subsidies are issued by the Ministry of Transport, Construction and Regional Development, according to the law concerning support of tourism (law No. 91/2010, Coll.). The regional budgets, university budgets, or European Union (EU) structural funds can be introduced as other possibilities of financing from public resources. Financing from the public resources is important, especially during the initial phases of the cluster life cycles. The financing of the clusters by the private sector is utilized to a smaller extent. The financial contributions of the cluster's member companies through membership fees or sponsorships by persons other than cluster members belong here. Financing from the private resources is utilized during the later phases of the cluster life cycle; the membership fees are critical (Pavelková et al., 2009).

\footnotetext{
${ }^{1}$ University of Žilina, denisa.janasova@fbi.uniza.sk

${ }^{2}$ University of Žilina, stanislava.strelcova@fbi.uniza.sk
} 
The Slovak Innovation and Energy Agency (SIEA) provides support in the form of information to the clusters. The Slovak Innovation and Energy Agency published an analytical study, Clusters for Support of Innovations in 2009 and is considered the first publication mapping the situation with clusters in the Slovak Republic (Duman et al., 2009). Another analytical study was published in 2015, Cluster Policy in the Conditions of Slovakia (Balog, 2015). The list of clusters operating in the Slovak Republic on the website of the agency SIEA was last updated in 2009, and that in the Cluster Policy in the Conditions of Slovakia in 2010. Nonetheless, the organization, European Cluster Observatory (ECO), provides a more up-to-date list of cluster and cluster policy analyses in Europe. The statistical data about clusters that are available is current to 2011. The Cluster Union of Slovakia deals with the activities for supporting the cluster policy development in the Slovak Republic as well as other activities. This union was established in 2010. Currently, there are 11 members (the clusters of different orientations) with the union participating in various international projects. The union currently cooperates in the framework of the project V4 Clusters Go International, which is aimed at building international cluster capacities and orientation in new markets (Únia, 2016).

\section{Forms of Cross-Border Cooperation in Cluster Area}

A cluster offers a space for establishing an internationally competitive business, and thus, needs to provide information about the international markets, trends, and innovations. Therefore, a necessary task faced by the cluster organization, and the companies involved, is to achieve international cooperation. The international cooperation from the perspective of clusters can be classified by the following groups:

- the international cluster initiative,

- the domestic cluster with foreign participation,

- the cross-border cluster, and

- the cross-border cooperation of clusters.

The cluster initiative is understood as an organized activity aimed at improving the level and competitiveness of the cluster organizations (Duman et al., 2009). The group of the international cooperation can involve establishing various supporting policies, strategies, projects, and institutions at the EU level, e.g., the European Cluster Alliance or European Cluster Policy Group.

A domestic cluster with foreign participation represents cooperation based on membership or collaboration with a foreign company as well as an educational or research institution. This group can be divided, according to the involvement of the foreign participant in the domestic cluster, into these sub-groups:

- a foreign subject is a member of the domestic cluster,

- a foreign subject is the founder member of the domestic cluster, and

- the collaboration of the domestic cluster with a foreign company.

The domestic cluster with foreign participation arises under a certain legal form. In the Slovak Republic, the legal forms are predominantly, 1) an interest association of legal entities and 2) citizens' association. The domestic cluster with foreign participation is financed predominantly by the subsidies of the domestic country and membership fees.

A cross-border cluster arises based on requests of various programs aimed at cross-border cooperation. It is established where a project involves domestic and foreign participants delivering on common goals. Participants in the framework of a cross-border cluster cooperate to achieve the goals of the project, including building and strengthening foreign relations. An example of a cross-border cluster is the Hunting and Forestry Cluster of Economic Cooperation and Nature Protection in the border area of Hungary and the Slovak Republic. Another is the Czech-Slovak-Polish Cluster aimed at common projects in the area of the road, railway, and building construction, and another, the Czech and Slovak Industrial Cluster of Collaboration of East Moravia and West Slovakia. European Union funds, governmental co-financing, and, to a smaller extent, co-financing of involved participants and partners, help finance projects of the cross-border clusters, as compared to a domestic cluster with foreign participation, financed through subsidies and membership fees.

The cross-border cooperation of the clusters develops with the same orientation across particular economic activities of several countries. An example is the cooperation of the Automotive Cluster of 
the Slovak Republic and Moravia-Silesian Automotive Cluster. Another involves the cooperation between the Slovak Plastic Cluster, Czech Plastic Cluster, and the Industrial Cluster Bydgoski. Hence, several examples exist of such a cluster collaboration between countries.

The activities aimed at improving the level of the cluster organizations by the government and the participants of both the public and private sector should be oriented towards creating particular measures according to the structure of the clusters in the Slovak Republic. The mapping activities of the clusters' orientation in the Slovak Republic play a major role in such. The analytical study Cluster Policy in the Conditions of Slovakia (Balog, 2015) identifies a list of 16 clusters that have been active in the Slovak Republic up until 2010. This study aims to identify the current number of Slovak Republic clusters and their orientation.

\section{Data and Methodology}

The study examined a group of clusters active in the Slovak Republic. A list of these clusters was created to investigate their number and orientation and to analyze their structure. The exact name and orientation of individual clusters are excluded from publication. Particulars for the list were obtained from the registers of 'the interest associations of the legal entities' and 'citizens' associations,' published by the Ministry of Interior of the Slovak Republic (Registre, 2016). For extraction, the keyword 'cluster' was entered into the search field of the registers (for each name). Then, the list was expanded by adding organizations other than those found under the keyword 'cluster.' First, these were the organizations, Biterap, IT Valley, Z@ict, and Celim Slovakia, which were shown on the websites of SIEA and ECO as clusters. Next, the interested associations that applied for subsidies to support industrial clusters and which had been approved by the Ministry of Economy of the Slovak Republic were added to the list. These applicants included the Association for Development of the Region Horná Nitra and the Slovak Centre of Productivity. Further, the list of clusters was completed by identifying the interest associations that contained the words 'development of the region' in their names, as in the case of the cluster Association for Development of the Region Horná Nitra (an applicant for subsidies for a cluster). Overall, 70 clusters were identified, out of which 23 had the legal form 'citizens' association.'

Each clusters was assigned as having a particular orientation using the orientations given in the abovementioned registers of the Ministry of Interior of the Slovak Republic. The representation of the identified clusters was compared to that of the companies by ranking the companies according to the more general classification based on the results of Malé (2016, p. 71).

In creating the list, the study had these main limitations. Firstly, it was not possible to identify all cluster organizations operating in the Slovak Republic using the above methods. Secondly, having a record in the register of interested or citizens' associations did not guarantee that the cluster was active. Thirdly, the cluster organization could have had another legal form that inevitably introduces a word other than 'cluster' in its name. Finally, it was not possible to identify an exact definition, or a border when it meant designating a given association of the companies or other cooperating participants without a closer specification or as a cluster. Nonetheless, it was considered that the list provided a general survey of clusters within the Slovak Republic and thus, a theoretical basis for deriving possibilities for developing a cluster initiative and policy in the area of the Slovak Republic.

\section{Results and Discussion}

Of the 70 clusters identified, approximately $19 \%$ were aimed at 'tourism,' $30 \%$ belonged to the classification 'regional development', and $51 \%$ were oriented towards a particular industry activity (Figure 1). The clusters classified under industry involved 10 areas (Figure 1). The scientific research and the development of various specializations were the major industrial area. This was followed by clusters of the engineering industry; energetics industry; information and communication technologies; electrical engineering and technics; agriculture and food industry; transport; and waste disposal and environmental protection. In contrast, the collaboration in the building industry and processing of plastic materials was not that common, with only one cluster in each.

The majority of clusters in the Slovak Republic arose during 2014. Of the 70 clusters included in the research, 12 were registered in that given year; a number that was three times that of the previous two years. These 2014 registrations were mainly clusters in tourism as well as associations that were not 
previously present in the Slovak Republic at that time, e.g., transport (railway and air transport) and an agricultural and food cluster.

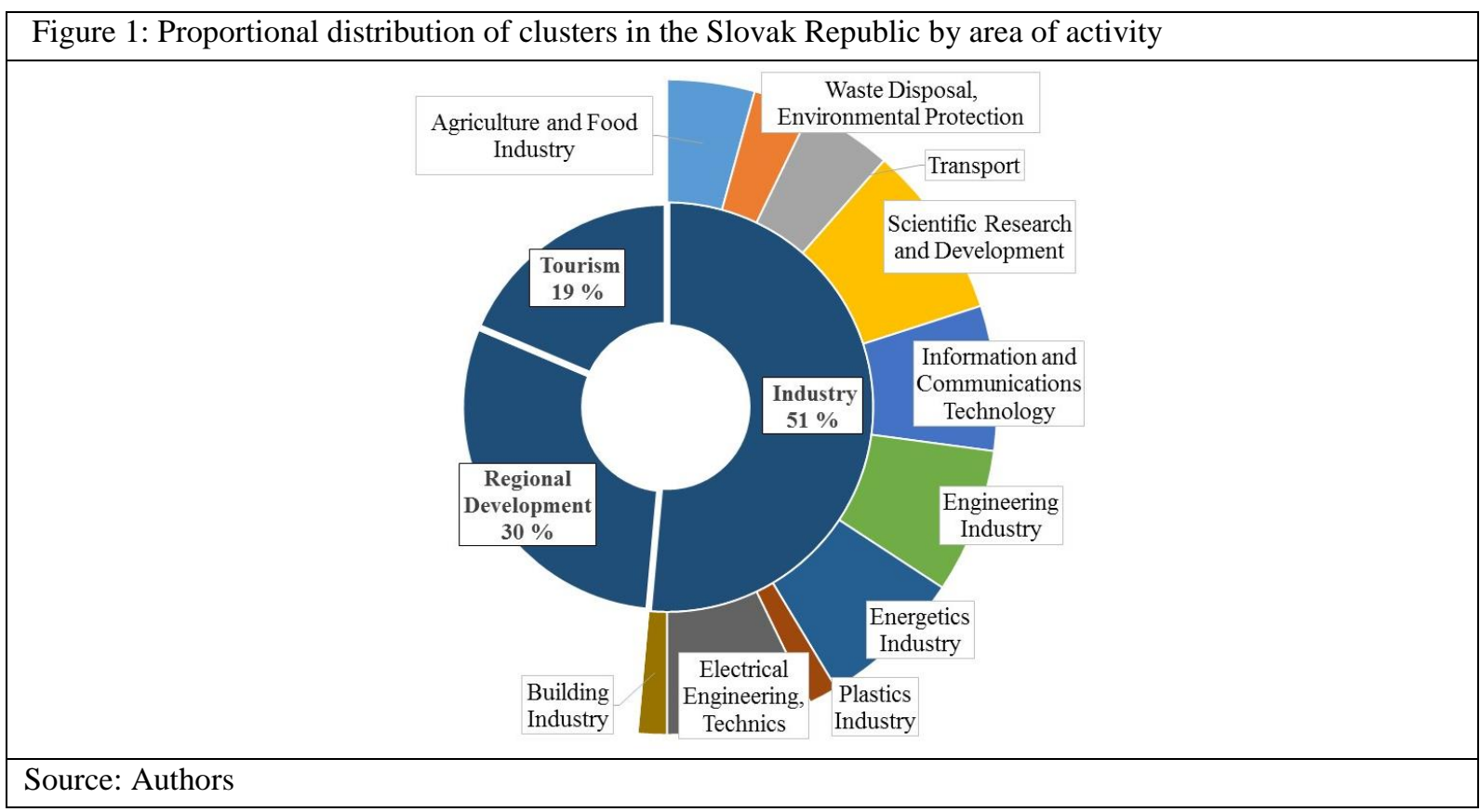

The abovementioned analytical studies (Duman et al., 2009; Balog, 2015) grouped cluster organizations into two classifications: technology and tourism. This study used three classifications: tourism, industry, and region development (Figure 1). The tourism clusters in the Slovak Republic involved participants in tourism from a certain region or in a popular tourist area. The second group, the regional development, comprised clusters with participants in various lines of business in the same region. Their aim was to increase the competitiveness of the region through activities oriented toward improving the economic activity, erudition, reducing unemployment, protecting the environment, and supporting tourism. The industrial clusters involved participants situated in another region, but with the same orientation in economic activity, i.e., in the same line of business.

The cluster initiative can be oriented toward either supporting the existing clusters or creating suitable conditions for building new cluster organizations. The support of the existing clusters could be oriented toward improving the cluster promotion and their advantages. This research found several cluster organizations had no website, which meant it was difficult to gather information about them. In this respect, the clusters could be losing potential members. A solution would be to create a common internet portal to record clusters and their basic information. Thus, the companies and other potential members would have an overview of the active clusters in their territory or with the same or similar orientation. A cluster initiative aimed at supporting the rise of new clusters needs to be concentrating especially on increasing areas that are currently lacking in the Slovak Republic and which will assumably attract interest from members of the public and private sector. These clusters especially correspond to those lines of business in which a large number of companies operate.

Figure 2 compares the percentage represented by each identified cluster with that of the companies operating in the Slovak territory. The economic activities of agriculture and food industry, scientific research and development, and information and communications technology in the clusters closely matched that represented by companies in the Slovak Republic (Figure 2). The building industry had the biggest discrepancy in the framework of comparing the cluster and company orientation (Figure 2). There were many companies in the building industry, but the cluster representation of such (only one) was minimal (Figure 2). In contrast, regarding the percent share, there were more clusters aimed at electrical engineering and technics than companies operating in this area (Figure 2).

The building industry had the largest representation of companies that were manufacturing enterprises (Figure 2). A comparison of the structure of the clusters and companies aimed at production showed a lack of clusters involved with wood and metal processing (Figure 2). There were few companies 
producing plastic (rubber) products, or in engineering or electrical engineering and technics (Figure 2). However, the clusters that associate with this specialization were identified.

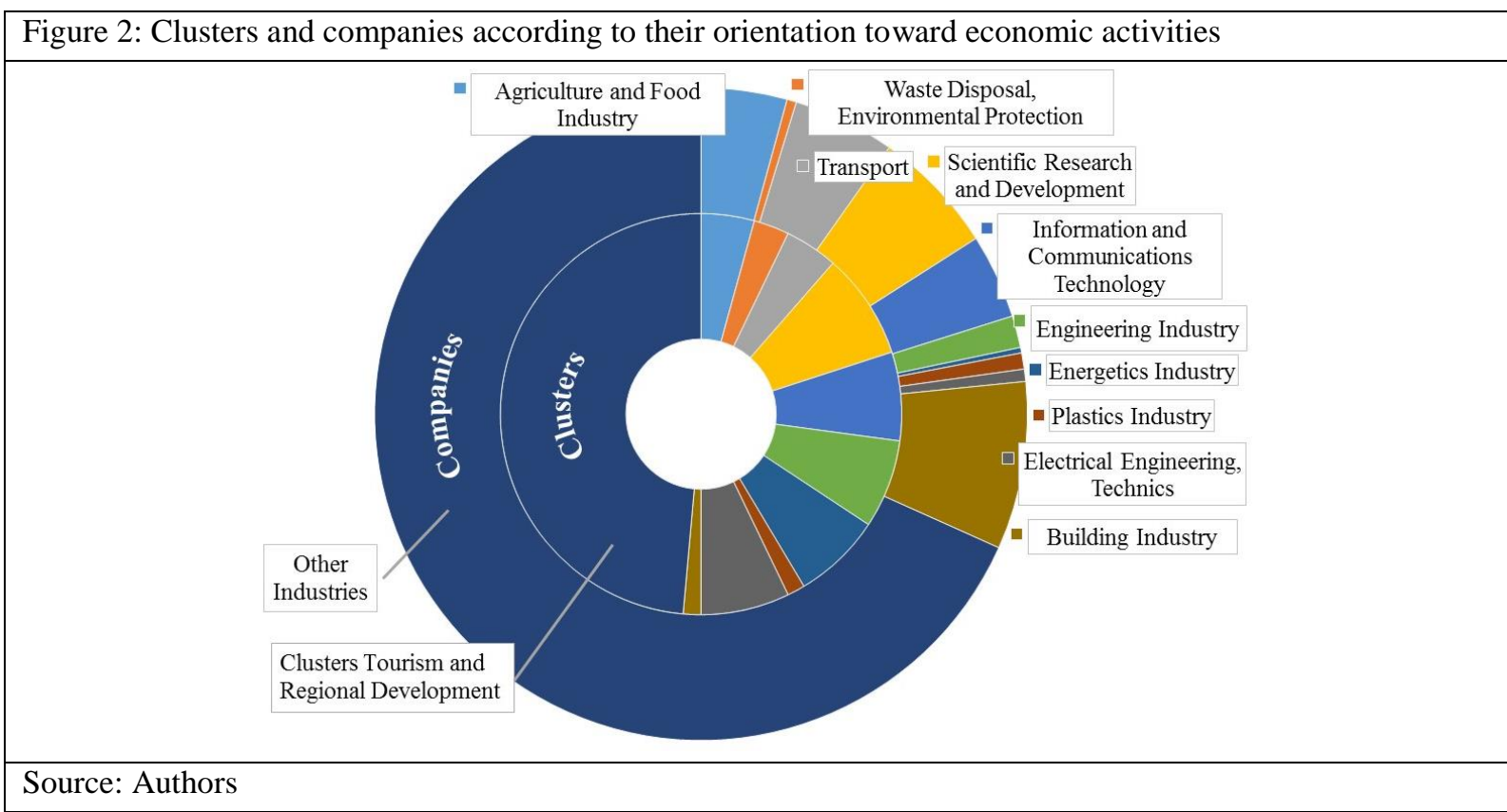

Figure 3 depicts the lines of business of the major active enterprises outside of a cluster. These enterprises especially include economic activities oriented towards services. The majority of legal entities in the Slovak Republic operate in the wholesale and retail business. The next largest is the sector of legal, accounting and consultancy activities, followed by administrative and support services, and then activities in the area of estates (Figure 3).

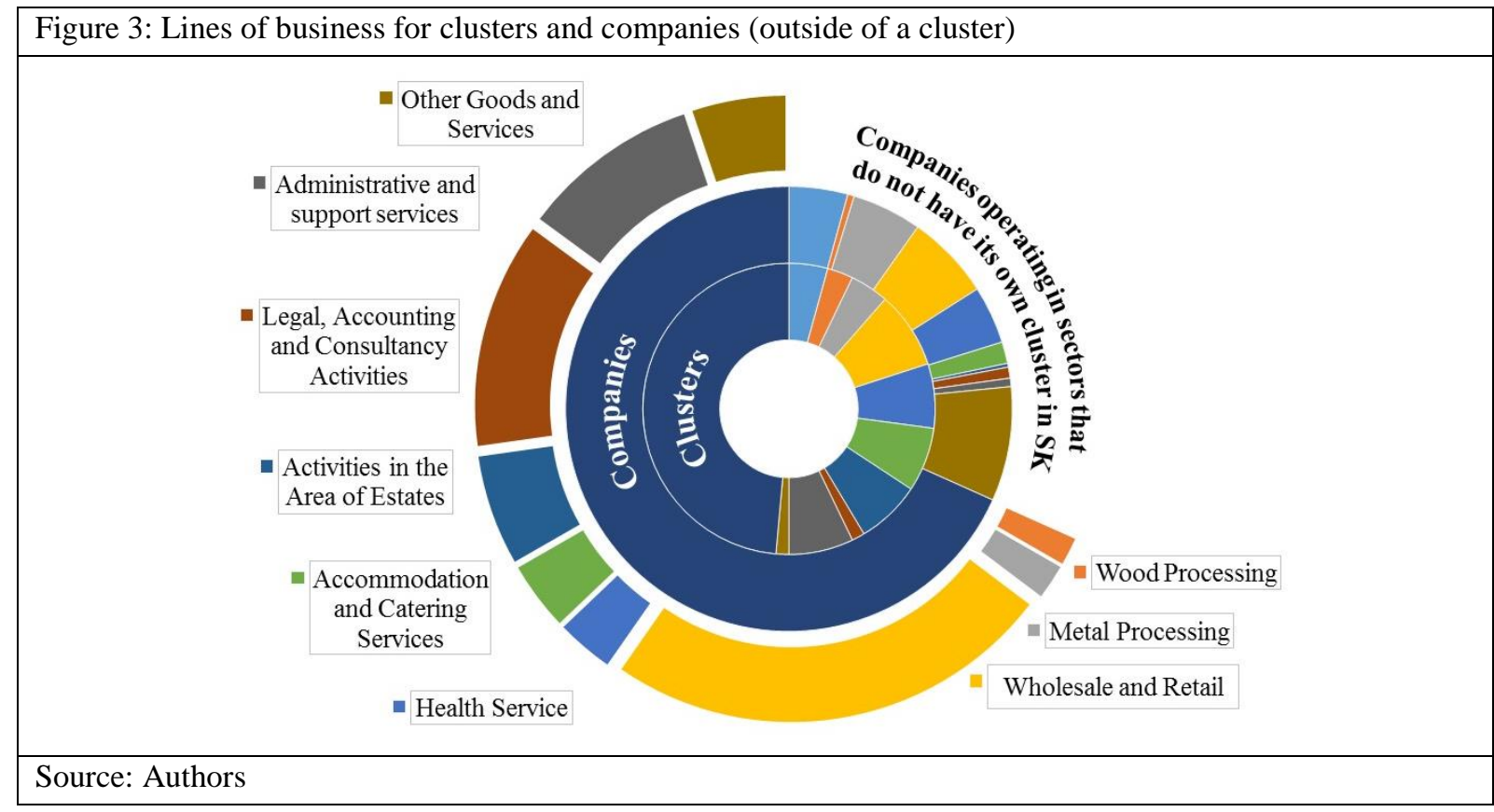

It is noted that the companies operating in the lines of business shown in Figure 3 could overlap in cluster organizations, e.g., the companies aimed at accommodation and catering services could be members of a tourism cluster. As tourism is not an interdepartmental line of business, the tourism clusters can also be associated with companies of another orientation. The companies operating in these lines of business could be members in those clusters ranked in the group 'region development'. These clusters are associated with companies of various lines of business that operate in a particular region. 


\section{Conclusion}

A cluster initiative represents a set of activities aimed at improving the level and competitiveness of clusters. These activities are oriented especially towards financial support and providing information for the clusters. The type of state subsidy for financing a cluster depends on the legal form and orientation of the cluster. The Slovak Innovation and Energy Agency provides international support by way of information for the clusters or other institutions. This current analysis found that an updated list of clusters is needed for the cluster initiative of the Slovak Republic. An analysis of the cluster structure was based on a list of 70 clusters (exact names and orientations are not published). The information for creating a list of clusters operating in the Slovak Republic was obtained from records about 'the interest associations of the legal entities' and 'citizens' associations.' This article compares the percentage of companies represented in a line of business with those of clusters identified in the study Despite limitations in the compilation. The list provides a general overview of the clusters in the Slovak Republic and therefore, creates a basis for further research in this area.

\section{Acknowledgements}

This paper was created with the support of the projects VEGA 1/0560/16 Risk Management in SMEs in the Slovak Republic - Prevention of Corporate Crisis and IGP 201606 Management of business risks as a process of adaptation to changes in the corporate environment.

\section{References}

Balog, M. (2015). Klastrová politika v podmienkach Slovenska [Web blog post]. Retrieved from https://www.siea.sk/materials/files/inovacie/publikacie/studia_SIEA_Klastrova_politika_web.pdf

Duman, P., Balog, M., Rehák, Š., Zaušková, A. \& Loučanová, E. (2009). Klastre na podporu rozvoja inovácií. Analytická štúdia. [Web blog post]. Retrieved from https://www.siea.sk/materials/files/inovacie/slovenske_klastre/Klastre-SIEA.pdf

Kaliňák, M. (2012). Podnikatelia a klastre môžu žiadat’ o podporu aplikovaného výskumu. Bratislava: MŠVVaŠ SR. [Web blog post]. Retrieved from https://www.minedu.sk/podnikatelia-a-klastre-mozu-ziadat-o-podporu-aplikovaneho-vyskumu/

Malé a stredné podnikanie v číslach v roku 2015. (2016). Bratislava: Slovak Business Agency. [Web blog post]. Retrieved from http://www.sbagency.sk/sites/default/files/msp_v_cislach_v_roku_2015_0.pdf

Pavelková, D. et. al. (2009). Klastry a jejich vlyv na výkonnost firem. Praha: GRADA Publishing. ISBN 978-80-247-2689-2

Porter, M. E. (1998). The Competitive Advantage of Nations: with a new introduction. New York: Free Press. ISBN 0-68484147-9

Registre a evidencie. (2016). Bratislava: MV SR. [Web blog post]. Retrieved from http://www.ives.sk/registre/

Schéma na podporu priemyselných klastrových organizácií (schéma pomoci de minimis). (2014). Bratislava: MH SR. [Web blog post]. Retrieved from https://www.siea.sk/materials/files/inovacie/klastre_dotacie/2014/Schema_DM-

18_2014_klastre.pdf

Únia klastrov Slovenska. (2016). [Web blog post]. Retrieved from http://uksk.sk/

Zákon č. 71/2013 Z. z. o poskytovaní dotácií v pôsobnosti Ministerstva hospodárstva SR

Zákon č. 91/2010 Z. z. o podpore cestovného ruchu

Zoznam schválených žiadostí o poskytnutie dotácie v roku 2016. (2016). Bratislava: Ministerstva hospodárstva SR. [Web blog post]. Retrieved from http://www.minv.sk/?zoznam-schvalenych-ziadosti-o-poskytnutie-dotacie-v-roku-2016 